\title{
Use of fluted pumpkin (Telfairia occidentalis) leaf powder as feed additive in African catfish (Clarias gariepinus) fingerlings
}

\author{
Adekunle Ayokanmi DADA \\ Department of Fisheries and Aquaculture Technology, Federal University of Technology, \\ Akure, Ondo State, Nigeria \\ E-mail: dadaayokanmi@yahoo.com,aadada@futa.edu.ng,Tel: +2348064364831
}

\begin{abstract}
The effect of dietary Telfairia occidentalis leaf meal on growth, heamatological profile and body composition was investigated in African catfish Clarias gariepinus. Fingerlings of about $5 \mathrm{~g}$ were fed diets supplemented with four concentrations $\left(5,10,15\right.$ and $\left.20 \mathrm{~g} \mathrm{~kg}^{-1}\right)$ of $T$. occidentalis leaf powder for eight weeks. Fish fed supplemented diets showed significantly improved growth performance, haematological parameters and feed utilization over the control $\left(0 \mathrm{~g} \mathrm{~kg}^{-1} T\right.$. occidentalis leaf meal $)$ treatment. The highest specific growth rate $\left(7.33 \pm 2.37 \% \mathrm{day}^{-1}\right)$ and best food conversion ratio $(0.86 \pm 0.06)$ were obtained in the $5 \mathrm{~g} \mathrm{~kg}^{-1} T$. occidentalis leaf meal diet treatment. Protein efficiency ratio was higher in fish fed with $T$. occidentalis leaf meal and lowest in the control. No differences occurred in fish carcass moisture, protein or ash content among the treatments $(p>0.05)$. The results suggest that dietary supplementation with $T$. occidentalis leaf powder improved growth; feed utilization and survival of $C$. gariepinus fingerlings.
\end{abstract}

(c) 2015 International Formulae Group. All rights reserved.

Keywords: Medicinal plant, growth performance, blood parameters, carcass composition, mudfish.

\section{INTRODUCTION}

The African catfish, Clarias gariepinus is the most extensively cultured food-fish species in Nigeria. High feed costs have forced producers to examine ways to reduce production costs. One of the ways to reduce costs is through the use of dietary supplements that include plant-based additives.

The use of plant-based additives in aquaculture is one of the methods used to improve weight gain, feed efficiency, and/or disease resistance in cultured fish. Therefore, several kinds of plant-based additives for aquafeed that are used to improve the performance of fish have been studied: plant products such as Astragalus radix and Scutellaria radix (Yin et al., 2006); Allium sativum (Sahu et al., 2007); Mango (Awad and Austin, 2010) and Nigella sativa (Awad et al., 2013) .These plants have been examined in fish to replace antibiotic growth promoters. For example, phytogenic feed additives have been examined in African catfish (Dada and Oviawe, 2011) and Tilapia (Dada, 2012) and results show improvements in weight gain, food conversion ratio (FCR), and blood indices.

Telfairia occidentalis (fluted pumpkin) is cultivated in various parts of southern Nigeria. The darkish green leafy vegetable is used as food and herbal medicine. The leaf is 
a rich source of protein, oil, vitamins and minerals but low in crude fiber and also rich source of folic acid, calcium, zinc, potassium, cobalt, copper, iron, vitamins $\mathrm{A}, \mathrm{C}$ and $\mathrm{K}$ (Ajibade et al., 2006).

Telfairia occidentalis leaf contains active ingredients such as bioflavonoid, an active chemical, a plant growth promoter, which promotes growth in birds (Fasuyi and Nonyerem, 2007), and may have similar effects in fish. The leafy vegetables possess anti-microbial and antiviral properties (Nwozo et al., 2004; Olorunfemi et al., 2005). Aqueous extract of $T$. occidentalis is also reported to increase hematological parameters (Alada, 2000). The objective of this study was to investigate the effects of dietary concentration of $T$. occidentalis leaf meal on growth, body composition and haematological parameters of $C$. gariepinus fingerlings.

\section{MATERIALS AND METHODS}

Four diets based on a formulation of 41.3\% protein, 9.08\% lipid and 5.35\% Ash were prepared to contain different levels of fluted pumpkin (T. occidentalis) leaf powder. Fluted pumpkin leaf powder was incorporated into the diets as follows: no Fluted pumpkin (control), 0.5 (group 1), 1.0 (group 2), 1.5

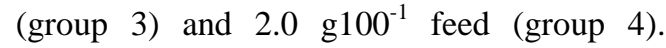
Fluted pumpkin at different incorporation was added to pelletized feed and then feed were separately dried at ambient temperature (27$\left.30{ }^{\circ} \mathrm{C}\right)$. Pellets were packed and stored in tightly sealed plastic bags at $8-10^{\circ} \mathrm{C}$ until they were used in the feeding experiments.

225 Clarias gariepinus fingerlings (mean body weight: $5.17 \pm 0.06 \mathrm{~g}$ ) were obtained from a commercial fish farm in Akure, Nigeria and transferred to the department of fisheries and aquaculture technology hatchery at Federal University of Technology, Akure, Ondo State. Fish were randomly allocated between 15 tanks in triplicate at a density of 15 fish per 52 litres rectangular plastic troughs and maintained in continuously aerated dechlorinated fresh water. During the experiment, the following conditions were maintained: water temperature $26.70 \pm 0.85{ }^{\circ} \mathrm{C}$, dissolved oxygen concentration $5.20 \pm 0.48 \mathrm{mg} / \mathrm{l}$ and $\mathrm{pH}$ $7.01 \pm 0.07$. After 14 days adaptation, fish in each group were fed one of the four different diets at a total daily rate of $3 \%$ body weight in three equal meals, every five hours between 08:00 and 18:00 for eight weeks. All fishes were weighed and counted fortnightly and feeding rates were adjusted accordingly.

At the termination of the feeding trial, 5 fish in each tank were individually weighed $24 \mathrm{~h}$ after the last feeding. Specific growth rates (SGR), feed conversion ratio (FCR) and protein efficiency ratio were calculated as indicators for growth performance (Heidarieh et al., 2012).

$\mathrm{FCR}=$ total feed given/total weight gain

$\mathrm{SGR}=100 \times[(\ln W f-\ln W i) /$ days $]$,

Where $W f$ is mean final weight and $W i$ is mean initial weight

PER $=$ Live body weight gained $(\mathrm{g}) /$ Protein intake $(\mathrm{g})$

Where: Protein Intake $(\mathrm{g})=$ Protein $(\%)$ in feed $\times$ Feed given $(\mathrm{g}) / 100$

The diets were analyzed for proximate composition, including crude protein, crude lipid, crude fibre, ash and moisture (Table 1).

Water temperature, $\mathrm{pH}$ and dissolved oxygen concentration were routinely monitored in all tanks. At the beginning and end of the feeding trial, pooled samples of 15 fingerlings were analyzed for carcass composition using AOAC (2005) procedures. Twelve fish (four fish per replicate) were used for blood analysis and $5 \mathrm{ml}$ blood samples from each treatment were collected by cardiac puncture using $5 \mathrm{ml}$ disposable syringes, into treated Bijou bottles. The blood was stored at $-40{ }^{\circ} \mathrm{C}$ prior to analysis. The blood analysis followed the methods described by Svobodova et al. (1991).

\section{Statistical analysis}

Analysis of variance (ANOVA) was used at $95 \%$ significance level to test for significant differences between the various treatment means obtained for the growth, feed 
utilization, carcass composition and haematological parameters. Tukey's multiple range tests was used to determine which pairs of the treatment means differed significantly (Zar, 1996).

\section{RESULTS}

Mean water quality parameters during the experiment were: dissolved oxygen $5.20 \pm$ $0.48 \mathrm{mg} \mathrm{l}^{-1}, \mathrm{pH} 7.00 \pm 0.07$ and $26.7 \pm 0.85$ ${ }^{\circ} \mathrm{C}$. Water quality parameters were not significantly different between treatments and were within the recommended ranges for the culture of C. gariepinus

There were improvements in the growth responses of fish fed on $T$. occidentalis leaf meal. The best growth responses were obtained in the fish fed on diet D2 $\left(0.5 \mathrm{~g} 100^{-1}\right.$ of $T$. occidentalis leaf powder) while the slowest growth was obtained in the fish fed the control diet D1 (Table 2). However, there were no significant differences in growth performance across the different $T$. occidentalis leaf concentrations. The results suggest that dietary $T$. occidentalis leaf at all concentrations promoted the growth of $C$. gariepinus fingerlings. This is a first report regarding the potential of fluted pumpkin leaf powder as a growth-promoting agent in C. gariepinus.

There were greater improvements in the feed conversion ratio (FCR) of fish fed on T. occidentalis leaf meal than the control fish. The average FCRs were 0.86, 1.32, 1.44 and 1.33 for diets D2, D3, D4 and D5 respectively. The PER was $0.07,0.04,0.03$ and 0.04 for the fish fed diets D2, D3, D4 and D5 respectively. Fish fed on T. occidentalis meal had a significantly $(p<0.05)$ higher protein content than fish fed the control diet. The body composition values are given in Table 3. These results showed that the $T$. occidentalis leaf meal treatment enhances nutrient utilization, which is reflected in improved weight gain, FCR, PER and SGR. Generally, better feed conversion ratio values were obtained in all treatments, but the

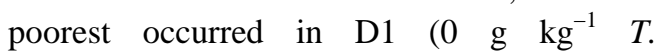
occidentalis leaf meal) (Table 2). Although better FCR values were obtained in the $T$. occidentalis dietary treatments compared to the control, differences among the treatment means were not significant $(p>0.05)$.

Table 1: Ingredient composition $(\mathrm{kg})$ and proximate composition (\% DM) of basal diet.

\begin{tabular}{|c|c|}
\hline Ingredients & g/kg diet \\
\hline Menhaden fish meal & 250 \\
\hline Corn meal & 150 \\
\hline Soybean meal & 350 \\
\hline Blood meal & 100 \\
\hline Cod liver oil & 60 \\
\hline Vegetable oil & 40 \\
\hline Vitamin-mineral premix & 30 \\
\hline Corn starch & 20 \\
\hline \multicolumn{2}{|c|}{ Proximate composition (\%) } \\
\hline Crude protein & 41.3 \\
\hline Crude lipid & 9.08 \\
\hline Ash & 5.35 \\
\hline Gross energy (Kcal/g) & 4.65 \\
\hline
\end{tabular}


Table 2: Mean growth performance and feed utilisation of $C$. gariepinus fingerlings fed experimental diets for 56 days.

\begin{tabular}{|c|c|c|c|c|c|}
\hline \multirow[t]{2}{*}{ Parameter } & \multicolumn{5}{|c|}{ Dietary treatment } \\
\hline & D1 (Control) & D2 & D3 & D4 & D5 \\
\hline Initial mean weight $(\mathrm{g})$ & $5.11(0.08)$ & $5.12(0.07)$ & $5.21(0.07)$ & $5.27(0.06)$ & $5.13(0.02)$ \\
\hline Final mean weight $(\mathrm{g})$ & $6.76(0.09)^{\mathrm{a}}$ & $9.23(0.24)^{\mathrm{a} b}$ & $7.26(0.51)^{b c}$ & $7.04(0.15)^{\mathrm{c}}$ & $7.55(0.62)^{\mathrm{d}}$ \\
\hline Weight gain $(\mathrm{g})$ & $1.622(0.09)^{\mathrm{a}}$ & $4.11(0.33)^{\mathrm{a} b}$ & $2.05(0.33)^{\mathrm{a} b}$ & $1.78(0.06)^{\mathrm{b}}$ & $2.42(0.94)^{\mathrm{c}}$ \\
\hline PER & $0.03(0.00)^{\mathrm{a}}$ & $0.07(0.02)^{b c}$ & $0.04(0.01)^{\mathrm{a} b}$ & $0.03(0.00)^{\mathrm{c}}$ & $0.04(0.01)^{\mathrm{c}}$ \\
\hline $\operatorname{SGR}\left(\%\right.$ day $\left.^{-1}\right)$ & $2.89(0.16)^{\mathrm{a}}$ & $7.33(0.37)^{\mathrm{a}}$ & $3.65(0.60)^{\mathrm{a}}$ & $3.17(0.11)^{\mathrm{b}}$ & $4.32(0.67)^{\mathrm{b}}$ \\
\hline FCR & $1.53(0.14)^{\mathrm{a}}$ & $0.86(0.60)^{b c}$ & $1.32(0.40)^{\mathrm{a} b}$ & $1.44(0.51)^{\mathrm{c}}$ & $1.33(0.59)^{\mathrm{c}}$ \\
\hline $\mathrm{FI}(\mathrm{g} / \mathrm{d})$ & $2.48(0.08)^{\mathrm{a}}$ & $2.65(0.09)^{b c}$ & $2.56(0.00)^{\mathrm{a} b}$ & $2.57(0.05)^{\mathrm{c}}$ & $2.58(0.14)^{\mathrm{c}}$ \\
\hline
\end{tabular}

Table 3: Chemical composition of whole body of $C$. gariepinus fingerlings fed experimental (wet basis).

\begin{tabular}{lccccc}
\hline Composition (\%) & \multicolumn{5}{c}{ Dietary treatment } \\
\cline { 2 - 6 } & D1 (control) & D2 & D3 & D4 & D5 \\
\hline Moisture & $4.83(0.42)^{\mathrm{a} b}$ & $4.31(0.31)^{\mathrm{b}}$ & $4.73(0.40)^{\mathrm{a}}$ & $4.59(0.07)^{\mathrm{a} b}$ & $4.78(0.42)^{\mathrm{a}}$ \\
Crude protein & $60.76(0.00)^{\mathrm{a}}$ & $61.75(0.28)^{\mathrm{a}}$ & $61.13(0.56)^{\mathrm{a}}$ & $61.46(0.00)^{\mathrm{a}}$ & $61.42(0.10)^{\mathrm{a}}$ \\
Crude lipid & $5.00(0.20)^{\mathrm{a}}$ & $4.51(007)^{\mathrm{a}}$ & $4.88(0.03)^{\mathrm{a}}$ & $3.96(0.69)^{\mathrm{a}}$ & $5.05(0.06)^{\mathrm{a}}$ \\
Ash & $13.62(0.20)^{\mathrm{a}}$ & $13.49(0.33)^{\mathrm{a}}$ & $11.89(0.51)^{\mathrm{a}}$ & $13.20(0.91)^{\mathrm{a}}$ & $12.85(0.00)^{\mathrm{a}}$ \\
\hline
\end{tabular}

Means in a given row with the same superscript letter were not significantly different at $p<0.05$. Values in parentheses are standard errors of means. 
Table 4: Some haematological characteristics of $C$. gariepinus fed the experimental diets.

\begin{tabular}{lccccc}
\hline & \multicolumn{5}{c}{ Experimental diets } \\
\cline { 2 - 6 } Blood parameter & D1 & D2 & D3 & D4 & D5 \\
\hline PCV $(\%)$ & $37.5(2.50)^{\mathrm{d}}$ & $37.5(1.50)^{\mathrm{bc}}$ & $29.0(3.00)^{\mathrm{a}}$ & $30.0(1.00)^{\mathrm{a}}$ & $32.0(1.00)^{\mathrm{cd}}$ \\
$\mathrm{Hb}(\mathrm{g} / 100 \mathrm{ml})$ & $12.50(0.08)^{\mathrm{c}}$ & $12.60(0.50)^{\mathrm{b}}$ & $9.65(0.95)^{\mathrm{a}}$ & $10.00(0.30)^{\mathrm{b}}$ & $10.75(0.35)^{\mathrm{b}}$ \\
$\mathrm{WBC}\left(\times 10^{3} / \mu \mathrm{l}\right)$ & $5150(95.0)^{\mathrm{a}}$ & $5550(25.0)^{\mathrm{c}}$ & $8050(12.50)^{\mathrm{e}}$ & $8050(45.0)^{\mathrm{d}}$ & $6750(10.50)^{\mathrm{b}}$ \\
$\mathrm{RBC}\left(\times 10^{6} / \mu \mathrm{l}\right)$ & $1.18(0.28)^{\mathrm{d}}$ & $1.45(0.15)^{\mathrm{bc}}$ & $3.20(0.35)^{\mathrm{a}}$ & $3.30(0.10)^{\mathrm{a}}$ & $3.58(0.18)^{\mathrm{cd}}$ \\
\hline
\end{tabular}

Means in a given row with the same letter were not significantly different at $p<0.05$. Values in parentheses are standard errors of means. $\mathrm{PCV}=$ packed cell volume, $\mathrm{H} \mathrm{b}=$ haemoglobin estimation, $\mathrm{WBC}=$ white blood cell count, $\mathrm{RBC}=$ red blood cell count.

\section{DISCUSSION}

T. occidentalis leaf powder in diets promoted growth and feed conversion efficiency in birds (Fasuyi and Nonyerem, 2007). Similar results were reported by Turan (2006) who used the medical herb red clover Trifolium pratense as a growth-promoting agent for tilapia Oreochromis aureus. Diab et al. (2002) also reported that Nile tilapia $O$. niloticus fingerlings fed on diets supplemented by medicinal plants exhibited faster growth than those fed with the control diet. Similar results were reported for using medicinal plants as growth-promoting agents for common carp Cyprinus carpio (Yilmaz et al., 2006), guppy Poecilia reticulata (Cek et al., 2007a), the cichlid Cryptoheros nigrofasciatus (Cek et al., 2007b), tilapia Oreochromis niloticus (Metwally, 2009) and African catfish C. gariepinus (Dada and Oviawe, 2011). Fallahpour et al. (2014) suggested that unknown factors in various medicinal herbs led to favourable results in fish growth trials.

The present findings may indicate that the presence of bioflavonoids in $T$. occidentalis stimulate growth in fish. In addition, bioflavonoid are plant chemicals with estrogenic activity, and studies have shown that estrogen promotes growth in common carp (Kocour et al., 2005). Therefore, the T. occidentalis leaf powder that promotes growth performance in the African catfish should be tested for its efficacy to induce efficient and economical propagation in other fish. The best feed utilization values observed with diets supplemented with $T$. occidentalis leaf meal suggested that the addition of $T$. occidentalis leaf meal improved feed utilization.

The haematological parameters of $C$. gariepinus (Table 4) showed no significant differences in mean cell volume, mean corpuscular haemoglobin concentration, mean cell haemoglobin or pack cell volume in all the treatments. However, there was a significant difference in the white blood cell count of fish among the treatments. Fish fed on diets supplemented with $T$. occidentalis leaf meal had significantly higher white blood cell counts.

White blood cell counts were significantly higher in fish fed diets including $0.5,1.0,1.5$ and $2.0 \mathrm{~g} / 100$ of $T$. occidentalis leaf powder. The haematological values obtained in the present study are similar to those obtained by Dada and Oviawe (2011) who used G. kola as a growth-promoting agent in C.gariepinus fingerlings. Differences in blood parameters of fish in this study could therefore be ascribed to differences in the dietary inclusions of $T$. occidentalis leaf meal in the diets.

The body composition values obtained in this study were similar to those reported by Diab et al. (2002), Lara-Flores et al. (2003), Hamid and Mohamed (2008) and Fallahpour et al. (2014). 


\section{Conclusion}

Results from the aforementioned study indicate promising potential and reliable method for propagating fingerlings production and rearing strategy. The use of medicinal plants, especially of fluted pumpkin in catfish, will be an efficient tool to achieve sustainable, economical, and safe fish production. Future research should focus on the improvement of rearing technologies for different species of fish reared using $T$. occidentalis leaf powder as a feed supplement.

\section{REFERENCES}

Ajibade SR, Balogun MO, Afolabi OO, Kupolati MD. 2006. Sex differences in the biochemical contents of Telfairia occidentalis. Hook f. Journal of Food Agriculture Environ., 4: 155-156.

Alada ARA. 2000. The haematological effects of Telfairia occidentalis diet preparation. African Journal of Biomed. Res., 3(3): 185-186.

AOAC. 2005. Official Methods of Analysis. $\left(18^{\text {th }}\right.$ edn). Association of analytical chemist international. Arlington Virginia, USA, 1141.

Awad E, Austin B. 2010. Use of lupin, Lupinus perennis, mango, Mangifera indica, and stinging nettle, Urtica dioica, as feed additives to prevent Aeromonas hydrophila infection in rainbow trout,

Oncorhynchus mykiss (Walbaum). Journal of Fish Diseases, 33: 413-420.

Awad E, Austin D, Lyndon AR. 2013. Effect of black cumin seed oil (Nigella sativa) and nettle extract (Quercetin) on enhancement of immunity in rainbow trout, Oncorhynchus mykiss (Walbaum). Aquaculture, 388-391: 193-197.

Cek S, Turan F, Atik E. 2007a. The effects of gokshura, Tribulus terrestris, on sex differentiation of guppy, Poecilia reticulata. Pak. J. Biol. Sci., 10: 718-725.

Cek S, Turan F, Atik E. 2007b. Masculinization of convict cichlid (Chichlasoma nigrofasciatum) by immersion in Tribulus terrestris extract. Aquacult Internat., 15: 109-119.

Dada AA, Oviawe NE. 2011. The use of bitter kola Garcinia kola dry seed powder as a natural growth-promoting agent for African sharptooth catfish Clarias gariepinus fingerlings. African Journal of Aquatic Science, 36(1): 97-100.

Dada AA. 2012. Effects of herbal growth promoter feed additive in fish meal on the performance of nile tilapia (Oreochromis niloticus L.). Egypt Acad. J. Biolog. Sci., 4(1): $111-117$.

Diab AS, El-Nagar OG, Abd-El-Hady MY. 2002. Evaluation of Nigella sativa L. (black seeds, Baraka), Allium sativum (garlic) and Biogen as feed additives on growth performance and immunostimulants of Oreochromis niloticus fingerlings. Suez Canal Vet. Med. J., 2: 745-753.

Fallahpour F, Banaee M, Javadzade N. 2014. Effects of dietary marshmallow (Althaea officinalis L.) extract on growth performance and body composition of common carp (Cyprinus carpio). Int. J. Adv. Biol. Biom. Res., 2(8): 2453-2460.

Fasuyi AO, Nonyerem AD. 2007. Biochemical, nutritional and haematological implications of Telfairia occidentalis leaf meal as protein supplement in broiler starter diets. Afr. J. Biotechnol., 6: 1055-1063.

Hamid EB, Mohamed KA. 2008. Effect of using probiotics as growth promoters in commercial diets for monosex Nile tilapia (Oreochromis niloticus) fingerlings. In Proceedings of the Eighth International Symposium on Tilapia in Aquaculture, 12-14 October 2008, Cairo, Egypt, Elghobashy H, Fltzsimmons K, Dlab AS (eds); 241-252.

Heidarieh M, Mirvaghefi AR, Akbari M, Farahmand H, Sheikhzadeh N, Shahbazfar AA, Behgar M. 2012. Effect of dietary Ergosan on growth performance, digestive enzymes, intestinal histology, hematological 
parameters and body composition of rainbow trout (Oncorhynchus mykiss). Fish Physiol. Biochem., 38(4): 11691174.

Kocour M, Lynhard O, Gela D, Rodina M. 2005. Growth performance of all-female and mixed-sex common carp, Cyprinus carpio L. population in central European climatic conditions. J. World Aquacult., Soc., 36: 103-113.

Lara-Flores M, Olvera-Novoa MA, GuzmanMendez BE, López-Madrid W. 2003. Use of the bacteria Streptococcus faecium and Lactobacillus acidophilus, and the yeast Saccharomyces cerevisiae as growth promoters in Nile tilapia (Oreochromis niloticus). Aquacul., 216: 193-201.

Metwally MAA. 2009. Effects of garlic (Allium sativum) on some antioxidant activities in Tilapianilotica (Oreochromis niloticus). World J. Fish Mar. Sci., 1: 5664.

Nwozo SO, Adaramoye OA, Ajaiyoba EO. 2004. Antidiabetic and hypolipidemic studies of Telfairia occidentalis on alloxan - induced diabetic rats. Nig. J. Nat. Prod. Med., 8: 45-47.

Olorunfemi AE, Arnold CI, Emmanuel O, Nkaima N, Akeem A. 2005. Hypoglycaemic activity of Telfairia occidentalis in rats. J. Pharm. Biores, 2: 36-42.

Sahu S, Das BK, Mishra BK, Pradhan J, Sarangi N. 2007. Effect of Allium sativum on the immunity and survival of Labeo rohita infected with Aeromonas hydrophila. J. Appl. Ichthyol., 23: 80-86.

Svobodova Z, Ravds D, Palackova J. 1991. Unified methods of haematological examination of fish. Arlington, Virginia: Research Institute of Fish Culture and Hydrobiology. Vonnony Czechoslovakia; 34.

Turan F. 2006. Improvement of growth performance in Tilapia (Oreochromis niloticus Linnaeus) by supplementation of red clover (Trifolium pretense) in diets. Bamidgeh, 58: 34-38.

Viveen WJAR, Richter CJJ, Van Oordt PG, Janssen JAL, Huisman EA. 1986. Practical manual for the African Catfish, Clarias gariepinus. Section for Research and Technology, Box 20061, 2500EB.

The Haque, Netherlands.

Yilmaz E, Genc MA, Cek S, Mazlum Y, Genc E. 2006. Effects of orally administered Ferula coskunii (Apiaceae) on growth, body composition and histology of common carp, Cyprinus carpio. J. anim. Vet. Adv. 5(12): 1236-1238.

Yin G, Jeney G, Racz T, Xu P, Jun X, Jeney Z. 2006. Effect of two Chinese herbs (Astragalus radix and Scutellaria radix) on non specific immune response of tilapia, Oreochromis niloticus. Aquaculture, 253: 39-47.

Zar JH. 1996. Biostatistical Analysis ( $3^{\text {rd }}$ edn). Prentice-Hall, Upper Saddle River: New Jersey, US; 383. 